\title{
DYNAMIC PANEL DATA ANALYSIS OF THE IMPACT OF INTELLECTUAL PROPERTY RIGHTS ON ENTREPRENEURSHIP IN EMERGING AND DEVELOPING COUNTRIES
}

\author{
Kamilia Loukil \\ Faculty of Economics and Management, University of Sfax, Sfax - Tunisia \\ kamilia.loukil@gmail.com
}

\begin{abstract}
Entrepreneurship is considered as a key driver of economic growth and development. That is why, scholarly contributions have set out to identify its national determinants. In the present study, we aim to shed some light on to how the institutional framework affects the entrepreneurship levels, by focusing on emerging and developing countries. More specifically, this study examines the impact of intellectual property rights (IPR) on entrepreneurship in emerging and developing countries. This issue is becoming increasingly important, especially in the context of developing countries which adhere to the Trade Related Intellectual Property Rights Agreement (TRIPS). Further to this agreement, all member countries of the world trade organization are required to achieve high standards of IPR. From the theoretical analysis, it appears that the impact of IPR on innovative entrepreneurs is positive, while their impact on imitators is more ambiguous. To empirically test these hypotheses, we apply a System Generalized Method of Moments (System GMM) technique on a panel of 28 countries during the period 2005-2012. The entrepreneurship level is measured by the new business entry density while the protection degree of intellectual property rights is measured by the IPR index of World Economic Forum. The findings show a non-significant effect of IPR on new business entry. We conclude that the intellectual property rights are not an effective tool of industrial policy in emerging and developing countries. Governments should rely on other factors in order to spur entrepreneurship.
\end{abstract}

Keywords: entrepreneurship, innovative entrepreneurs, imitators, intellectual property rights, emerging and developing countries.

JEL Classification: $\mathrm{K} 11, \mathrm{O} 3, \mathrm{O} 25$

\section{Introduction}

Entrepreneurship is increasingly seen as a key driver of economic development (Baumol, 1990; Wennekers and Thurik, 1999; Minniti and Lévesque, 2008). It fosters innovation, enhances employment creation and ensures more equitable income distribution (Baumol, 1990; Acs, 2006).

Due to the beneficial role of entrepreneurship in economic growth and development, scholarly contributions have set out to identify its national determinants. Researchers have considered economic, institutional and psychological factors that may explain differences in the levels of entrepreneurial activity. In this paper we examine the institutional environment. According to North (1991), institutions are the humanly devised constraints that structure political, economic and social interactions. They consist of both informal constraints (sanctions, taboos, customs, traditions, and codes of conduct), and formal rules (constitutions, laws, property rights). Institutions can both enable behaviors and constrain them.

While the question concerning what determines the level of entrepreneurship in developed countries is well studied, much less attention has been given to the determinants of 
entrepreneurship in developing countries. Therefore, the purpose of this paper is to shed some light on to how the institutional framework, especially, the Intellectual Property Rights (IPR), affect the entrepreneurship level in emerging and developing countries. This issue is becoming increasingly important especially in the context of developing countries which adhere to the Trade Related Intellectual Property Rights Agreement (TRIPS). Further to this agreement, all member countries of the world trade organization are required to achieve high standards of IPR.

Our study aims to enrich existing literature by examining the impact of IPR on entrepreneurship for 28 countries between 2005 and 2012. To estimate our dynamic panel data model, we employ a System Generalized Method of Moments (System GMM) technique. The System GMM estimation technique is more efficient than the traditional twoway fixed effect model. It addresses the endogeneity problem more accurately by using internal instruments for endogenous variables. It jointly estimates the equation in first difference and in the levels-first difference instrumented by lagged levels of the dependent and explanatory variables and levels instrumented by first differences of the regressors. Our estimated results show a non-significant impact of intellectual property rights on entrepreneurship.

The remainder of the paper is organized as follows: In Section 2 we discuss theoretical issues and empirical results relative to previous studies. In Section 3 we introduce the data and empirical methodology. Our empirical findings are presented and discussed in Section 4. Section 5 contains our conclusions.

\section{Literature review}

\subsection{The concept of entrepreneurship: Definition}

Entrepreneurship is defined in several ways. Schumpeter (1934) points out that entrepreneurship takes place when there is an innovation, that is, when an introduction of new products, organizations or processes occurs. According to him, entrepreneurship is related to the creation of new combinations. Therefore, a person who creates a new business by imitating existing firms is not an entrepreneur in the Schumpeterian sense. In his article "Entrepreneurship: productive, unproductive and destructive", Baumol (1990) distinguishes between several forms of entrepreneurship. He stresses that entrepreneurs are defined as persons who are ingenious and creative in finding ways that add to their own wealth, power, and prestige. The general environment plays an important role in determining each type of entrepreneurship, that can either be productive or unproductive. According to Baumol, the choice of entrepreneurs between good and bad business depends on their relative performance. Therefore, there must be adequate incentives and institutions to better pay for productive entrepreneurship.

The GEM (Global Entrepreneurship Monitor) studies employ two categories of entrepreneurship: opportunity and necessity entrepreneurship. Opportunity entrepreneurship refers to new firm formation based on innovation. Necessity entrepreneurship takes place in countries with a high unemployment rate, like in the case of developing countries.

Minniti and Lévesque (2010) distinguish between research-based entrepreneurs and imitators. When a country has a research and development infrastructure, a potential entrepreneur can take advantage of this context in order to become a research-based entrepreneur. But, if there is an underdeveloped R\&D infrastructure, the entrepreneur will be an imitator, in that he would take advantage of the innovations of entrepreneurs from other countries. This is the case of most developing countries. In these countries, human capital is low and technologies are so poor that they cannot invest in R\&D, but they may benefit from technology transfers that will contribute to their economic development. 
In this paper, we prefer this last categorization as we focus on developing countries. Therefore, we define entrepreneurship as a process of starting up a business based on research and innovation (innovative entrepreneurs) or on imitation (imitators).

\subsection{IPR and entrepreneurship: Theoretical framework}

According to several scholars (North and Thomas, 1973; Williamson, 1985; Barzel, 1997), property rights systems form the backbone of the modern set of institutions that characterize the market economy. Acemoglu and Johnson (2005) show that property rights have pronounced effects on investment, financial development and long run economic growth.

Parker (2007) notes that well protected property rights help promote entrepreneurship and innovation. In addition, weaker property rights are likely to foster the development of predatory forms of entrepreneurial activities (Henrekson, 2007).

Intellectual property rights form the most important component of property rights, relevant for both types of entrepreneurs: innovators and imitators.

For the case of innovative entrepreneurs, the positive link between the protection of intellectual property rights and the formation of new firms is explained by Baumol (1993). Indeed, the later points out that entrepreneurs tend to operate in areas that offer the highest financial returns. Thus, entrepreneurs' activities vary according to the reward structure of the economy. When this structure changes, for market, political or institutional reasons, entrepreneurs will be the first economic agents to identify and respond to the opportunities generated by these changes. Strengthening IPR protection in a given country can change the structure of the economy's rewards by increasing the potential returns generated by investments in innovation activities and allows for formation of a new firm in order to exploit these innovations.

For the case of imitators, the impact of IPR protection on entrepreneurial income is ambiguous (Kihlstrom and Laffont, 1979; Evans and Jovanovic, 1989). If IPR protection laws act to restrict access to technology for imitative firms, then a negative effect will dominate. On the other hand, if IPRs create new profit opportunities for new firms by creating new opportunities that can be imitated and exploited perfectly by new small businesses, then they will have a positive impact on a country's entrepreneurial activity.

In this case, the question is whether the marginal effect of the IPR on the stock/pool of knowledge on which the entrepreneur is basing his imitation is more important than their marginal effect on the restriction of access to this stock of knowledge by intensifying the monopolistic power of innovators. So, in this paper we try to evaluate what is the dominant effect.

\subsection{IPR and entrepreneurship: Overview of literature}

A number of empirical studies examine the relationship between IPR protection and entrepreneurship. For example, Desai et al. (2003) analyze institutions and entrepreneurial activity in Europe and find that there is more entrepreneurship in countries with better property rights among the emerging economies in Eastern Europe, but that this effect is attenuated for the advanced economies in Western Europe.

Pissarides et al. (2003) study small and medium enterprises in Russia and Bulgaria. They find that the insecurity of property rights is not a constraint, but that financing is the major constraint of entrepreneurs operating in these countries.

Claessens and Laeven (2003) found that industries that rely on intangible assets show a disproportionately lower rate of growth in countries characterized by weak intellectual property rights.

Estrin et al. (2011) find no significant impact from intellectual property rights on entrepreneurship in 55 countries for the 2001-2006 period. 
Livramento and Foray (2007) show that for developed countries, increases in the IPR regime positively affect the formation of high growth expectation entrepreneurship but this relationship is negative for developing countries.

Using the GEM surveys for 42 countries over the 1998-2005 period, Estrin et al (2009) analyze how institutional environment and entrepreneurial characteristics affect the decisions of individuals to become entrepreneurs and their aspirations to set up highgrowth ventures. They find that institutions exert different effects on entrepreneurial entry and on the individual choice to launch high-growth aspiration projects. In particular, a strong property rights system is important for high-growth aspiration entrepreneurship, but has less pronounced effects for entrepreneurial entry.

From a survey of new firms in post-communist countries, Johnson et al. (2002) find that weak property rights discourage firms from reinvesting their profits.

Klapper (2006) find that there is more entry in R\&D intensive industries in countries that better protect property.

Using data on 1,397 patents assigned to the Massachusetts Institute of Technology during the 1980-1996 period, Shane (2001) shows that the effectiveness of patent protection is one factor that influences the likelihood that a new technology will be exploited through firm formation.

\section{Methodology}

\subsection{Sample description}

Our sample includes 28 emerging and developing countries. The period of study is from 2005 to 2012. In this paper, we adopt the ranking of countries according to the report of the International Monetary Fund (IMF, 2012), which classifies countries into two categories: "Advanced Economies" and "Emerging and Developing Economies." Countries included in our sample are: Argentina, Bolivia, Brazil, Bulgaria, Chile, Colombia, Costa Rica, Egypt, EI Salvador, Hungary, Indonesia, Jamaica, Jordan, Latvia, Lithuania, Malaysia, Mexico, Morocco, Panama, Peru, Philippines, Poland, Romania, Russia, Thailand, Tunisia, Turkey, Uruguay.

\subsection{Measurement of variables}

\subsubsection{Dependent variable}

According to Klapper et al. (2010), entrepreneurship is identified as initiating economic activities via the legal process of starting a business. This definition implies that the rate of new business entry is an adequate measure of entrepreneurship in a country. In particular, for this paper, the entrepreneurship level (ENT) is measured by the new business entry density, which is defined as the number of newly registered limited liability corporations per calendar year, normalized by working age population. The same measure was used by Klapper et al. (2010), Klapper and Love (2011) and Hartwell (2014). The entry density variable is widely available, widely used and an internationally comparable metric. Moreover, the weighted nature of the indicator takes into account differing population sizes of countries.

The data are obtained from the World Bank's World Development Indicators.

\subsubsection{Independent variables}

To measure the protection degree of intellectual property rights (IPR), we follow Desai et al. (2003), Livramento and Foray (2007) and Estrin et al. (2011), and use the index of World Economic Forum which conducts a survey covering business leaders in various countries. The survey aims to see whether they view that intellectual property is well protected, with a scale ranging between 1 (disagree) and 7 (strongly agree). The average score for all 
respondents in a country gives the index for that country. The results of this survey are published in the Global Competitiveness Report (GCR). So, we have obtained data from different issues of that report.

The control variables are: GDP per capita (GDP); unemployment rate (UNEMP) and financial development level (FD).

The data on Purchase Power Parity (PPP) converted GDP per capita, at 2005 constant prices come from Penn World Table.

The unemployment rate refers to the share of the labor force that is without work but available for work and seeking employment.

The financial development is measured by domestic credit to private sector as share of GDP. The data on both unemployment and financial development comes from the World Bank's World Development Indicators (WDI).

To ensure normality of variables, we transform them in natural logarithm. Summary statistics for the variables (not logged in) are given in Table 1.

Table 1: Summary statistics

\begin{tabular}{|c|c|c|c|c|c|}
\hline & Mean & Median & Stand. dev & Minimum & Maximum \\
\hline ENT & 3.061 & 1.284 & 3.97 & 0.085 & 21.487 \\
\hline IPR & 3.438 & 3.5 & 0.631 & 1.7 & 5.1 \\
\hline GDP & 7379.084 & 7686.363 & 3667.897 & 1720.088 & 13963.67 \\
\hline UNEMP & 8.233 & 7.7 & 3.632 & 0.7 & 19.5 \\
\hline FD & 50.656 & 43.657 & 26.585 & 10.612 & 136.301 \\
\hline
\end{tabular}

\subsection{Econometric estimation}

We use the Generalised Method of Moments (GMM) to estimate our dynamic panel data model. This method is adequate for our case in which as mentioned by Mileva (2007), the panel dataset has a short time dimension $(T=8)$ and a larger country dimension $(\mathrm{N}=28)$. Moreover, it uses a set of instrumental variables to solve the endogeneity problem arising from the potential correlation between the independent variables and the error term in dynamic panel data models. It also permits to deal with omitted dynamics in static panel data models, owing to the ignorance of the impacts of lagged values of the dependent variable (Bond, 2002). Indeed, Holcombe (1998) notes that entrepreneurship generates more entrepreneurship. The business birth rate observed in the last period must explain the present rate.

To estimate our empirical model, we use the system GMM technique of Blundell and Bond (1998). The set of instruments of the system-GMM estimator includes not only all the available lags in difference of the endogenous variables and the strictly exogenous regressors but also the lagged values of the dependent variable (Blundell and Bond, 1998).

Our dynamic panel data model is represented as follow:

ENTit $=\beta 0+\beta 1$ ENTit-1 $+\beta 2$ IPRit $+\beta 3$ Xit $+\mu i+\varepsilon$ it

$\mathrm{i}=1, \ldots, \mathrm{N}$ denotes the country (in our study, $\mathrm{N}=28$ ) and $\mathrm{t}=1, \ldots \mathrm{T}$ denotes the time period (in our study, $\mathrm{T}=8$ ).

ENT is the entrepreneurship level, IPR is the indicator of intellectual property rights protection, $X$ is a vector of control variables, $\mu$ is an unobserved country-specific effect and $\varepsilon$ is the time-varying error term.

$\mathrm{X}=$ (GDP, UNEMP, FD).

Our estimations have been performed using the xtabond2 command in Stata 12. A crucial preliminary step in the estimation procedure consists of classifying the regressors as strictly exogenous, predetermined or endogenous variables. This classification has important 
implications in terms of the proper choice of instruments. In our model, we classified initial entrepreneurship, IPR index, GDP and financial development as endogenous variables. The predetermined variable is the unemployment rate. No variables were assumed to be exogenous.

\section{Findings}

Consistency of the GMM estimator depends on the validity of instruments. To address this issue, we consider three specification tests: the first is the Hansen test of over-identifying restrictions, which tests the overall validity of the instruments (the null hypothesis is that the instruments are valid). The second and third tests are the first and second-order autocorrelation test for error term, which tests the null hypothesis according to which there is no autocorrelation. As shown in Table 2, the p-value of Hansen test $(1.000>0.05)$ indicates that the used instruments are valid. The $p$-values of Arrelano-Bond test are 0.175 for $A R(1)$ and 0.078 for $A R(2)$, both greater than 0.05 . Therefore, there is no autocorrelation of the error term. Accordingly, we can conclude that the GMM system estimation is robust and appropriate.

Based on the GMM system estimation, we find that the effect of intellectual property rights on entrepreneurship is not statistically significant.

Of the control variables, we find evidence of positive effects on entrepreneurship of one year lagged value of entrepreneurship and GDP at $1 \%$ level. Moreover, results show that the financial development level has a negative effect, while unemployment rate does not have a significant effect on new business entry.

The main result of our study, that is the insignificant effect of IPR protection on new business entry density, is consistent with that of Estrin et al. (2011). They suggest that research and innovation-based entrepreneurs are more stimulated by the overall strength of the property rights system, rather than any single aspect such as intellectual property rights, to start up their business.

Our findings contradict those of Shane (2001) and Desai et al. (2003), who find a significantly positive effect of intellectual property rights on entrepreneurial activity. One possible explanation for this difference is that these studies focus on developed and not on developing countries.

Our result can be explained by an inadequate national innovation framework to facilitate entrepreneurial activities that are sensitive to IPR protection. It can also be explained by the fact that the protection of IPRs in developing countries leads to an intense monopolistic power granted to innovators. This causes the restriction of access to the stock of knowledge on which the entrepreneur can base his imitation, which prevents the creation of new businesses based on imitation.

We may also refer the cause of this null effect to the negative consequences of TRIPS agreement on developing countries. Indeed, it is important to note that the majority of entrepreneurs in developing countries are imitators. The strengthening of IPR protection raises the cost of investing in some activities because they are becoming "illegal". Indeed, some developing countries granted patents on drug manufacturing processes. This allows generic producers to copy a drug and design it in a new way by using different manufacturing processes. Now, and after adoption of the TRIPS agreement, this type of activity becomes illegal and producers are prohibited from transgressing drug patents invented and manufactured by developed countries. 
Table 2. System GMM model regression

\begin{tabular}{|c|c|c|}
\hline \multirow[t]{2}{*}{ Independent variables } & \multicolumn{2}{|c|}{$\begin{array}{c}\text { Dependant variable: ENT = new business } \\
\text { entry density }\end{array}$} \\
\hline & Coefficients $\beta$ & Standard Errors \\
\hline Constant & -6.63 & $2.482^{\star \star \star}$ \\
\hline L.ENT & 0.536 & $0.208^{\star \star \star}$ \\
\hline IPR & 0.166 & 0.128 \\
\hline GDP & 0.869 & $0.333^{\star \star \star}$ \\
\hline UNEMP & -0.062 & 0.044 \\
\hline FD & -0.222 & $0.121^{*}$ \\
\hline Observations & \multicolumn{2}{|r|}{195} \\
\hline Number of instruments & \multicolumn{2}{|r|}{67} \\
\hline Hansen $J$ test ( $p$-value) & \multicolumn{2}{|c|}{1.000} \\
\hline$A R(1)$ test ( $p$-value) & \multicolumn{2}{|c|}{0.175} \\
\hline AR(2) test (p-value) & \multicolumn{2}{|c|}{0.078} \\
\hline \multicolumn{3}{|c|}{$\begin{array}{l}\text { Coefficients and standard errors are given in this table. } \\
\star,{ }^{* *},{ }^{* *}: \text { coefficients are significant at } 10 \%, 5 \% \text { and } 1 \\
\% \text {. All variables are in natural logarithm. } \\
\text { L.ENT, IPR, GDP, UNEMP and FD denote respectively: lag of of } \\
\text { entrepreneurship, IP index of GCR, GDP per capita, unemployment rate and } \\
\text { domestic credit to private sector (\%GDP). }\end{array}$} \\
\hline
\end{tabular}

\section{Conclusion}

The aim of this study was to evaluate the role of entrepreneurial intellectual property rights in emerging and developing countries. Two categories of entrepreneurship are defined in this paper: innovative entrepreneurs and imitators. From the theoretical analysis, it appears that the impact of IPR on innovative entrepreneurs is positive, while their impact on imitators is more ambiguous. The empirical evidence shows that the effect of IPR on new business entry density in a set of emerging and developing countries is not statistically significant. Our study proves that emerging and developing countries have a poor national innovation framework, which unable to facilitate entrepreneurial activities that are sensitive to IPR protection. It also highlights the negative consequences of the TRIPS agreement on developing countries. We conclude that intellectual property rights are not an effective industrial policy tool in these countries. Governments should rely on other factors to spur entrepreneurship.

Our analysis suffers however from some weaknesses. For example, the metric of intellectual property rights is imprecise given the estimating of the quantitative impact, this is because of its ordinal nature and because the survey regarding the respondents' perceptions concerning what constitutes strong and weak IPR are likely to vary. For future research, we propose to use another indicator to measure the robustness of the IPR system and to compare the results found with those of the present study. 


\section{References}

Acemoglu, D. and Johnson, S. 2005. Unbundling institutions, Journal of Political Economy, 113, pp. 949-995.

Acs, Z. 2006. 'Start-ups and entry barriers: Small and medium-sized firms population dynamics', in M. Casson, B. Yeung, A. Basu, and N. Wadeson (Eds.), The Oxford handbook of entrepreneurship (pp. 194-224). Oxford University Press.

Arellano, M. and Bond, S. 1991. Some tests of specification for panel data: Monte Carlo evidence and an application to employment equations, The Review of Economic Studies, 58, pp. 277-297.

Bamford, C.E., Dean, T.J. and Douglas, T.J. 2004. The temporal nature of growth determinants in new bank foundings: Implications for new venture research design, Journal of Business Venturing, 19 (6), pp. 899-919.

Barzel, Y. 1997. The economic analysis of property rights, Cambridge: Cambridge University Press.

Baumol, W. 1993. Entrepreneurship, Management, and the Structure of Payoffs, Cambridge London: The MIT Press.

Baumol, W.J. 1990. Entrepreneurship : productive, unproductive and destructive, Journal of Political Economy, 98 (5), pp. 893-921.

Blundell, R. and Bond, S. 1998. Initial conditions and moment restrictions in dynamic panel data models, Journal of Econometrics, Elsevier, 87 (1), pp. 115-143.

Bond, S.R. 2002. Dynamic Panel Data Models: A Guide to Micro Data Methods and Practice, Portuguese Economic Journal, 1, pp. 141-162.

Claessens, S. and Laeven, L. 2003. Financial development, property rights, and growth, Journal of Finance, 58, pp. 2401-2436.

Desai, M., Gompers, P. and Lerner, J. 2003. Institutions, capital constraints, and entrepreneurial firm dynamics: evidence from Europe. NBER Working Paper no. 10165. Available at $\mathrm{https}: / /$ ideas.repec.org/p/nbr/nberwo/10165.html.

Estrin, S., Korosteleva, J. and Mickiewicz, T. 2009. Better means more: property rights and high-growth aspiration entrepreneurship. IZA Discussion Paper no. 4396. Available at https://www.researchgate.net/publication/46442957

Estrin, S., Korosteleva, J. and Mickiewicz, T. 2011. Which institutions encourage entrepreneurs to create larger firms? IZA Discussion Paper no. 5481. Available at http://ftp.iza.org/dp5481.pdf

Evans, D. and Jovanovic, B. 1989. An estimated model of entrepreneurial choice under liquidity constraints, Journal of Political Economy, 97 (4), pp. 519-535.

Evans, D.S. and Leighton, L.S. 1989. Some empirical aspects of entrepreneurship, American Economic Review, 79 (3), pp. 519-533.

Gaygisiz, E. and Koksal, M.Y. 2003. Regional variations in new firm formation in Turkey: Cross-section and panel data evidence. ERC Working Papers in Economics no. 03/08, September. Available at https://ideas.repec.org/p/met/wpaper/0308.html

Ginarte, J.C. and Park, W.G. 1997. Intellectual property rights and economic growth, Contemporary Economic Policy, 15, pp. 51-61.

Hartwell, C.A. 2014. Capital Controls and the Determinants of Entrepreneurship, Finance a úvěr-Czech Journal of Economics and Finance, 64 (6), pp. 434-457.

Henrekson, M. 2007. Entrepreneurship and institutions, Comparative Labor Law and Policy Journal, 28, pp. 717-742.

Holcombe, R. 1998. Entrepreneurship and Economic Growth, The Quarterly Journal of Austrian Economics, 1 (2), pp. 45-62.

IMF. 2012. Growth resuming, dangers remain, World Economic Outlook April 2012.

Johnson, S., McMillan, J. and Woodruff, C. 2002. Property rights and finance, The American Economic Review, 92 (5), pp. 1335-1356. 
Jovanovic, B. 1982. Selection and Evolution of Industry, Econometrica, 50, pp. 649- 670. Kauermann, G., Tutz, G. and Bruderl, J. 2005. The survival of newly founded firms: A casestudy into varying-coefficient models, Journal of the Royal Statistical Society Series AStatistics in Society, 168 (1), pp. 145-158.

Kihlstrom, R.E., and Laffont, J.J. 1979. A general equilibrium theory of firm formation based on risk aversion, Journal of Political Economy, 87 (4), pp. 719-748.

Klapper, L. and Love, I. 2011. The impact of the financial crisis on new firm registration, Economics Letters, 113 (1), pp. 1-4.

Klapper, L., Amit, R. and Guillén, M.F. 2010. Entrepreneurship and firm formation across countries, in J. Lerner, and A. Schoar (Eds.), International Differences in Entrepreneurship (pp.129-158). Chicago: University of Chicago Press.

Klapper, L., Laeven, L. and Rajan, R. 2006. Entry regulation as a barrier to entrepreneurship, Journal of Financial Economics, 82, pp. 591-629.

Livramento, I.M.H. and Foray, D. 2007. Does IPR protection affect high growth entrepreneurship? A cross-country empirical examination Working Paper. Available at http://citeseerx.ist.psu.edu/viewdoc/download?doi=10.1.1.574.3807\&rep=rep1\&type=pdf Lucas, R. E. 1978. On the Size Distribution of Business Firms, Bell Journal of Economics, 9, pp. 508-523.

Mileva, E. 2007. Using Arellano - Bond Dynamic Panel GMM Estimators in Stata. Tutorial with Examples using Stata 9.0 (xtabond and xtabond2). Working Paper.

Minniti, M. and Lévesque, M. 2008. Recent development in the economics of entrepreneurship, Journal of Business Venturing, 3 (6), pp. 603-612.

Minniti, M. and Lévesque, M. 2010. Entrepreneurial types and economic growth, Journal of Business Venturing, 25 (3), pp. 305-3014.

North, D. and Thomas, R. 1973. The rise of the western word: A new economic history, Cambridge: Cambridge University Press.

North, D.C. 1991. Institutions, The Journal of Economic Perspectives, 5 (1), pp. 97-112.

Oxenfeldt, A. 1943. New Firms and Free Enterprise, Washington, D.C.: American Council on Public Affairs.

Parker, S. 2007. Law and the economics of entrepreneurship, Comparative Labor Law and Policy Journal, 28, pp. 695-716.

Pissarides, F., Singer, M. and Svejnar, J. 2003. Objectives and constraints of entrepreneurs: evidence from small and medium-size enterprises in Russia and Bulgaria, Journal of Comparative Economics, 31, pp. 503-531.

Schumpeter, J.A. 1934. The theory of economic development, London: Transaction Publishers.

Shane, S. 2001. Technology regimes and new firm formation, Management Science, 47 (9), pp. 1173-1190.

Wenekers, S., Stel, A.V., Thurik, R. and Reynolds, P. 2005. Nascent entrepreneurship and the level of economic development, Small Business Economics, 24 (3), pp. 293-309.

Wennerkers, S. and Thurik, R. 1999. Linking entrepreneurship and economic growth, Small Business Economics, 13 (1), pp. 27-55.

Williamson, O. 1985. The economic institutions of capitalism. Firms, markets, relational contracting, New York: Free.

\section{Bio-note}

Kamilia Loukil is a PhD in Economics at the Faculty of Economics and Management of Sfax, Tunisia. Her main research interests refer to technological innovation, innovation policy and entrepreneurship in developing and emerging countries. 